DOI: 10.5817/CZ.MUNI.P210-6840-2014-81

\title{
ROLE OF BROWNFIELDS REGENERATION IN CONTEMPORARY REGIONAL POLICY
}

\section{MÍSTO REGENERACE BROWNFIELDŠ V SOUDOBÉ REGIONÁLNÍ POLITICE}

\section{Prof. PhDr. KAREL LACINA, DrSc.}

\author{
Katedra veŚsjné správy $\mid$ Department of Public Administration \\ Fakulta sociálních studii Faculty of Social Studies \\ Vysoká ǵkola finan! ní a správní $\quad$ Economics and Administration University \\ $\bowtie$ Estonská 500, 10100 Praha, Czech Republic \\ E-mail: kar.lacina@seznam.cz.
}

\begin{abstract}
Annotation
The existence of brownfields represents one of relatively significant problems complicating the longer-term municipalities and the whole regions development programs implementation. That is why their regeneration is considered generally to be topical. We are able to utilize in the Czech Republic the experience of the problem solution in some other European countries where the regeneration has a rich tradition - mainly from the United Kingdom and the Federal Republic of Germany.
\end{abstract}

Key words

brownfields, regeneration, protection of environment, derelict soil, municipalities and regional development plans, infrastructure construction

\section{Anotace}

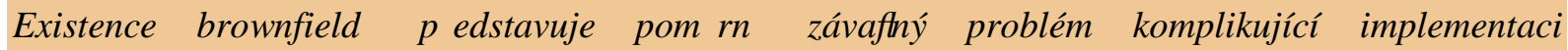
dlouhodobých program $\mathrm{J}$ rozvoje obcí a celých region $\mathrm{T}$. $Z$ uvedených $d \mathrm{~J}$ vod $\mathrm{T}$ je regenerace browfinfieldT pokládána za aktuální proces. $V$ Leské republice $m$ Tógeme vyuğvat zkuğenosti z Śġení dané problematiky vn nkterých evropských zemích, které maji s regenerace bohaté tradice ï pŚedevğ́m ze Spojeného království Velké Británie a Severního Irska a ze Spolkové republiky NDnecko.

\section{Klílová slova}

brownfieldy, regenerace,ochrana ğvotního prostŚsedi, kontaminovaná p Tda,municipální a regionální rozvojové plány, budování infrastruktury

\section{JEL classification: $X 12$}

\section{Negative influence of brownfields existence on municipalites and regions development}

Brownfields in the EU member states are generally considered to be a relatively large localities (with buildings of different quality) that are now outdated.As Ing.arch. VlaNka Jankových ï Kirschner stresses $\breve{A}$ the term brownfields was formed as the contraposition to the term greenfields. They are devastated areas having problems with their further utilization often due to the necessity of high investment into them.. They cause predominantly environmental, space, economic and socioeconomic problemsñ (Jankových, 2005).

Brownfields are also represented by spaces which were used for various agricultural and construction activities in the past. . According to National Brownfields Database Äbrownfield is an area utilized in the past for industrial, agricultural, construction or other activity ;it could be devastated é what is 
decreasing its attraction for the future utilizationñ (CzechInvest, 2008) One of brownfields features is the fact that many of them are contaminated nowadays by different chemical substances. Vast majority of brownfields could be, therefore, characterized as territories derelict especially due to the changes in selected industrial activities as well as the restructure of agricultural production.

What concerns the contemporary EU classification, brownfields are characterized either as ñderelict and vacant landsñ [ typically for Scotland ] or ñformally technically equipped landsñ [in England].Some of brownfields are also represented by the dumps of waste.

The majority of brownfields are:

- former mining areas;

- former metallurgical and other factories;

- former military bases and other spaces used by the army that are now often devastated;

- former agricultural facilities.

There is the consensus in the European Union Member States that brownfields represent the threats predominantly from the point of view of the protection of environment. Their negative influence is, however, much greater.

It is quite clear that if brownfields are not regenerated their existence would:

- diminish the competitiveness not only of individual municipalities but also of the whole regions;

- diminish the quality of life of those municipalities and regions;

- contribute to the acceleration of the migration of these territories inhabitants into regions with better environmental conditions;

- diminish the potential investors interest in industrial and other entrepreneurial activities;

- diminish the interests of tourists in such territories influencing $\ddot{i}$ among others - negatively the volume of financial resources for municipalities and regions development;

- diminish these territories presentation and promotion in exhibitions and other opportunities.

\section{Ways of brownfields effective regenerations}

ĂThe aim of brownfields regeneration is to increase the attraction and the value of individual localities to the level compatible with the construction in the greenfieldò(CzechInvest, 2008).

The experiences accumulated in European countries brownfields regenerations for decades confirm that there are three possible ways of this process implementation:

- Complete regeneration made exclusively only by the public administration (i.e. local government) authorities - on the basis of projects invested from public finances.

- Regeneration established by private developers - completely through projects financed from private resources.

- The unification of financial, other material and human potential of the public and private sectors on the basis of the municipalities and regions stakeholders close cooperation - based on projects financed from the public and private resources.

If the brownfields regeneration has been effective and efficient as well as if it respects the sustainable development principles the useful regeneration could be implemented, for example, on the basis of the Public - Private - Partnership approach. In such a way elected representatives of communities are fully responsible for:

- all decontamination activities;

- the reconstruction of some old buildings situated on the brownfield and for the construction of new ones;

- the infrastructure construction as well as

- making decisions concerning the possibly most effective utilization of the regenerated territory. 


\section{Some concrete examples of brownfields regeneration in EU member states}

A great experience from brownfields regeneration was accumulated predominantly in the United Kingdom. The first experience was made in the Central England - in the territory called ñBlack Country $\tilde{n}$ even in the period before the Second World War. The role of local government offices and authorities in brownfields regeneration was strengthened here in the beginning of the 1990s by the new Environmental Protection Act. Simultaneously the Agenda 21 principles started to be implemented in England, Scotland and Wales since that time - including in the sphere of brownfields regeneration. This orientation was further strengthened in April 2004 when the European Union Direction Nr. 2004/35/ES was approved in the EU level and started to be implemented in the British legal system. All mentioned legal standards underlined the local government representatives duty to identify the contaminated localities and to take care for their regeneration.

The mentioned activities are directed in the United Kingdom by the Development Agencies. A very active among them is the Scottish Development Agency (SDA) established in year 1974. It is predominantly oriented to the regeneration of localities damaged by the coal and slate mining and also in localities were the dominated position had the heavy industry for centuries. Vast majority of such regeneration projects are financed from the public financial resources till now. Every year about 150 million EURO are invested into the brownfields regeneration only in Scottland. The Scottish Development Agency cooperates closely with the organization named $\tilde{n}$ Scottish Homesò that constructs ï mainly around a very famous town Glasgow and in the Lanarkshire county - cheaper social flats in the regenerated areas.

Effective steps in the brownfields regenerations were made also in England, especially thanks to the activities of the organization called English Partnership established in the year 1994. Its principal duty is to identify all facilities capable for their regeneration and consecutively offered for:

- the modern industrial activities;;communal flats construction;

- recreation of the local inhabitants.

All these activities are considered to be very expensive but significant. That is why several Regional Development Agencies implementing the mentioned activities were founded in the year 1999. The idea of Public ï Private - Partnership in brownfields regeneration was implemented in England through the Land Restoration Trust established by the alliance of English Partnerships, Environmental Agency, the Forest Commission and the organization Groundwork. This alliance regenerated about 10000 hectars of brownfields in the period of ten years.

What concerns the restoration activities in Wales, it is coordinated by the Welsh Development Agency( WDA ) closely cooperated with the local government offices and authorities. More than 1300 such localities were regenerated and offered for different utilization only in the period till year 2000. This organization continued in the construction of approximately $60 \%$ of new houses in the regenerated localities during the first decade of the $21^{\text {st }}$ century.

Except of the United Kingdom a great experience from the brownfields regeneration was accumulated in the Federal Republic of Germany, predominantly in the Northern Rhine - Westvallen region.) This region represented the centre of the German mining and metallurgical industry since the half of the $19^{\text {th }}$ century and it has this position de facto till now. An interesting brownfields regeneration was implemented in the territory of the river Emsher basin (in the territory of about $800000 \mathrm{~km} 2$ ).Nearly $60 \%$ of the restoration costs were settled here by the European Union from its structural funds. About 500 hectars of restored land were offered to 1300 industrial enterprises for their utilization and approximately 1300 flats were constructed there. What concerns other EU member states, some precious experiences from brownfields restoration were achieved also in the northern and eastern French regions - most of them in the Nord - Pas de Calais and in the Lotrin regions. 


\section{European Union and brownfields regeneration}

The European Union pays a relatively great attention to the support of mentioned regeneration activities also in this time. Nowadays the EU members states are able to get supports predominantly in the Operational Program ñIndustry and Business ñ (the Priority Nr. 1 called ñEntrepreneurial Environment Development $\tilde{n}$ ). The program underlines the significance of:

- new building construction in the regenerated areas;

- modernization of buildings constructed in previous periods in that localities;

- possible brownfields transformation into greenfields.

Other possible source of financial supports for brownfields regenerations is the EU Cohesion fund from which money for activities aimed mainly at the improvement of the environmental situation are provided. Last but not least some money is possible to achieve in the form of credits from the European Investment Bank as well as from the European Bank for Reconstruction and Development.

EU member states are obliged to work out the National strategies of brownfields regeneration. The European Union authorities underline the position that those strategies could be successful only if their implementation is based on the consensus of all decisive political and other active forces of national states. Moreover, it was underlined for several times that such a consensus $\ddot{i}$ it means the consensus of all stakeholders - is extremely important for the brownfields concrete regeneration activities in the regions and localities.

\section{Conclusion}

The following conclusions could be adopted on the basis of the experience from the brownfields regeneration:

Brownfields regeneration represents the significant problem that is solved in the European continent approximately during the last fifty years. Nevertheless, the supranational European strategy was worked out and specified only since the second half of the 1970s, first of all thanks to the United Kingdom and Ireland membership in the European Communities.

Brownfields regeneration is made in the EU member states on the basis of the implementation of :

- projects financed from the public financial resources;

- projects financed by private entrepreneurs;

- projects implemented on the basis of public and private resources unification (predominantly through the Public ï Private - Partnership scheme).

The financing from the public resources (municipal, regional with the EU national state financial support) is, unfortunately, prevailing till now.

The experience of states with a relatively great number of regenerated areas show the fact that regenerated areas could be utilized especially for the following activities:

- construction of industrial zones and scientific parks;

- construction of communal houses (mainly for id families with low life standards);

- sport activities and leisure time facilitie;,

- business activities;

- offices rooms construction,;- building the parks.

The leading role in brownfields regeneration activities is played - from different reasons - by the public sector, first of all by the local government offices and authorities developing their activities in the local and regional levels. It is one of the lessons made in the EU members states fully possibly implemented in other countries will limited experience from the brownfields regeneration. 
There is a very interesting recommendation in some European Union member states that the approval of the buildings construction in greenfields should be accompanied by the same area of brownfields regeneration (for example the construction of buildings in 1 hectar of greenfields should be compensated by the regeneration of 1 hectar of the brownfield).

\section{References}

[1] JANKOVÝCH KIRSCHNER, V., (2005). Klasifikace brownfields. [studie k disertal ní práci]. Dostupné z: <http://www.brownfields.cz/wp-content/uploads/2007/11/studie-vjk-vladka-2005.pdf >

[2] CzechInvest., (2008). Národní databázebrownfieldT. Dostupné z <http://www.brownfieldy.cz/> 